\section{NFUDs nye styre}

På generalforsamlingen 2019 gikk hele det gamle styret av etter god innsats i mange år. Leder Kari Utne har vært i styret i hele seks år, mens Anette Hem, Kim Nylund, Sigrid Berg og Ruth Stoklund Thomsen alle har sittet i styret i fire år. Aurora Røset, Dina Ismail, Kjetil Myhr, Anders Batman Mjelle, Jan Henrik Opsahl og Geir Stene har bidratt i styret de siste to årene. NFUD og det nye styret takker for innsatsen!

Nytt blod og friske krefter har dermed kommet inn i NFUDs styre, og her følger en kort presentasjon av de nyvalgte.

Anesa Mulabecirovic er foreningens nye leder. Hun er utdannet lege og er doktorgradsstipendiat ved Universitetet i Bergen. Hennes interesse for ultralyd startet allerede på medisinstudiet, og i doktorgradsprosjektet, som omhandler leversykdommer og ultralyd, søker hun etter ny kunnskap om ultralyd elastografimetoder. I forbindelse med doktorgradsarbeidet har Anesa hatt et forskningsopphold ved Kings College London, et av de ledende sentrene for leversykdommer i verden. Parallelt med doktorgraden har hun tatt en master i økonomi ved Norges Handelshøyskole.

Maria von Krogh er valgt til nestleder og sekretær. Hun er snart ferdigutdannet spesialist i revmatologi, og jobber for tiden som konstituert overlege ved voksen- og barnerevmatologisk avdeling ved Oslo universitetssykehus, Rikshospitalet. Maria er spesielt interessert i bruk av ultralyd ved diagnostisering, behandling og oppfølging av revmatiske inflammatoriske sykdommer.

Karin Ulrike Deibele er valgt til kasserer i NFUDs nye styre. Hun er konstituert overlege ved kvinneklinikken ved St. Olavs hos- pital i Trondheim. Karin jobber med fostermedisin ved Nasjonal behandlingstjeneste for avansert invasiv fostermedisin.

Solveig Fadnes er styremedlem med ansvar for NFUDs foreningsblad Flaggermusen. Hun er utdannet sivilingeniør og har en doktorgrad i medisinsk teknologi fra NTNU. Både under doktorgradsarbeidet og senere som postdoc i ultralydgruppa ved NTNU (Institutt for sirkulasjon og bildediagnostikk) har blodstrømsavbildning i pediatrisk kardiologi vært hovedfokus. Solveig bor nå i Ålesund og fortsetter forskningen i samarbeid med Ålesund sykehus, St. Olavs Hospital og NTNU. Hovedfokus er å utvikle og forbedre ultralydmetoder for å oppdage og diagnostisere hjertefeil hos foster og barn.

Lars Petter Bjørnsen er styremedlem og har, sammen med Solveig, ansvar for Flaggermusen. Han jobber som akuttlege ved Mottaksavdelingen på St. Olavs hospital og er ansatt som førsteamanuensis ved NTNU i Trondheim. Han jobber klinisk i front som overlege og har utdanningsansvaret i mottaksavdelingen. Lars Petter har bred erfaring innen akutt- og mottaksmedisin og er spesialistutdannet i USA. Han bruker ultralyd daglig i evaluering og utredning av akutt syke og skadde pasienter, samt arrangerer og har vært instruktør på en rekke ultralydkurs innen fokusert akuttmedisinsk ultralyd.

Vibeke Skoura-Torvik er styremedlem med et spesielt ansvar for medlemsmassen til NFUD. Hun er jordmor med videreutdanning innen ultralyddiagnostikk for jordmødre. Hun har i 2018 fullført kurset “Doppler i obstetrikk. Maternelle og føtale blodkar, inklusive fosterhjertet”. Vibeke har jobbet både i fødeavdelingen og som kommune- jordmor, men jobber nå fulltid ved Nasjonal behandlingstjeneste for avansert invasiv fostermedisin. I tillegg er hun aktiv i Sorggruppa ved Kvinneklinikken på St. Olavs hospital og jobber med sorgstøtte for par som har opplevd dødfødsel.

Bjarte Sørensen er styremedlem med ansvar for NFUDs nettsider. Han ble uteksaminert med BSc(Med) MB BS fra UNSW, Australia i 2005 og er spesialist i allmennmedisin og Fellow of the Royal Australian College of General Practitioners (FRACGP). Han har siden 2007 vært fastlege ved Hjelmeland legekontor, to timer fra nærmeste sykehus. Han har brukt ultralyd i allmennpraksis i sju år og har spesiell interesse i svangerskap-, legevakt- og sykehjemsmedisin. Han er videre medlem i perinatalkomiteen Helse Vest, styremedlem Rogaland legeforening, og støttekollega i legeforeningens støttekollegaordning. Bjarte forsker for tiden på bruk av ultralyd i allmennmedisin og legevakt, og skriver på en systematisk oversiktsartikkel sammen med Steinar Hunskår ved Nasjonalt kompetansesenter for legevaktmedisin, med et stipend fra allmennmedisinsk forskningsutvalg.

Victoria Vatsvåg er styremedlem og sponsoransvarlig i NFUD. Hun har bachelor i radiografi fra Høgskolen i Bergen. I 2007 flyttet hun til Irland hvor hun jobbet som radiograf samtidig som hun startet videreutdanning i ultralyd. Hun jobbet som sonograf i Irland frem til 2013 og har siden jobbet ved Aleris Røntgen Stavanger. I tillegg til å jobbe klinisk har Victoria de siste to årene hatt stilling som Training Manager ved Prometheus Medical Nordic der hun har drevet med undervisning i ultralyd.

For mer informasjon, se www.nfud.no. 